\title{
A conceptual model to assess the impact of anthropogenic drivers on water-related ecosystem services in the Brazilian Cerrado
}

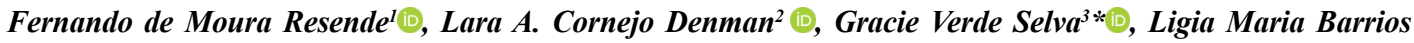

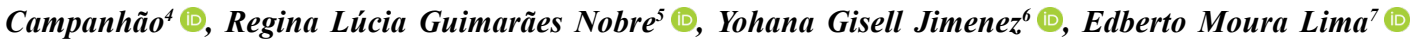 \\ \& Julia Niemeyer ${ }^{8}$ (1) \\ ${ }^{I}$ Universidade Federal de Minas Gerais, Departamento de Genética, Ecologia e Evolução, Belo Horizonte, \\ $M G$, Brasil. \\ ${ }^{2}$ Universidad de Sonora, Departamento de Investigaciones Cientificas y Tecnológicas, Hermosillo, Sonora, \\ México. \\ ${ }^{3}$ Instituto Brasileiro de Desenvolvimento e Sustentabilidade, Brasília, DF, Brasil. \\ ${ }^{4}$ Universidade de São Paulo, Escola de Engenharia de São Carlos, São Carlos, SP, Brasil. \\ ${ }^{5}$ Universidade Federal do Rio Grande do Norte, Departamento de Ecologia, Natal, RN, Brasil. \\ ${ }^{6}$ Universidad Nacional de Tucumán-Consejo Nacional de Investigaciones Científicas y Técnicas, Instituto de \\ Ecología Regional, Tucumán, Argentina. \\ ${ }^{7}$ Universidade Federal de Santa Maria, Departamento de Engenharia Florestal, Santa Maria, RS, Brasil. \\ ${ }^{8}$ Universidade Federal do Rio de Janeiro, Rio de Janeiro, RJ, Brasil. \\ *Corresponding author: Gracie Verde Selva, e-mail: gracieselva@gmail.com
}

RESENDE, F.M., DENMAN, L.A.C., SElVA, G.V., CAMPANHÃO, L.M.B., NOBRE, R.L.G., JIMENEZ, Y.G., LIMA, E.M., NIEMEYER J. A conceptual model to assess the impact of anthropogenic drivers on water-related ecosystem services in the Brazilian Cerrado. Biota Neotropica 20(suppl. 1): e20190899, https://doi.org/10.1590/1676-0611-BN-2019-0899

\begin{abstract}
The development of strategies that conciliate anthropogenic activities with nature conservation is becoming increasingly urgent, particularly in regions facing rapid conversion of native vegetation to agriculture. Conceptual modelling enables assessment of how anthropogenic drivers (e.g. land use/land cover change and climate change) modify natural processes, being a useful tool to support strategic decision-making. The present work describes a conceptual model to evaluate water-related ecosystem service provision under different land use scenarios in the Matopiba region of the Brazilian Cerrado, the world's most biodiverse savanna and an agricultural frontier. Model variables were determined (direct drivers, indirect drivers, focal components and responses) and the Nature Futures Framework was consulted to incorporate socio-ecological components and feedbacks. Future scenarios were developed considering potential trajectories of drivers and governance responses that may impact land use in the region, including the possibility of full compliance with Forest Code and implementation of the Soy Moratorium in the region. The conceptual model and scenarios developed in the present study may be useful to improve understanding of the complex interactions among anthropogenic drivers, water-related ecosystem services and their potential repercussions for natural and social systems of the region. Governance decisions will be critical to maintaining the ecosystems of the region, the services it provides and the culture and tradition of the people historically embedded in the landscape. In acknowledgment of humanity's dependence on nature, the importance of inverting the way scenarios are used is highlighted. Rather than using scenarios to measure the impacts of different policy options on nature, scenarios representing the desired outcomes for biodiversity and ecosystem services can be used to inform how policies can guarantee ecosystem integrity into the future.

Keywords: Nature's contributions to people; alternative scenarios; Nature Futures Framework; science-based policy; neotropical savanna; Forest Code; Soy Moratorium; Matopiba region.
\end{abstract}




\title{
Um modelo conceitual para avaliar o impacto de fatores antropogênicos nos serviços ecossistêmicos relacionados à água no Cerrado
}

\begin{abstract}
Resumo: O desenvolvimento de estratégias que conciliem atividades antropogênicas com a conservação da natureza tem se tornado cada vez mais urgente, principalmente em regiões que enfrentam uma rápida conversão da vegetação nativa em agricultura. Modelos conceituais permitem avaliar como fatores antropogênicos (por exemplo, mudança de uso e cobertura do solo e mudanças climáticas) modificam os processos naturais, sendo uma ferramenta útil para apoiar a tomada de decisões estratégicas. O presente trabalho descreve um modelo conceitual para avaliar a provisão de serviços ecossistêmicos relacionados à água sob diferentes cenários de uso do solo na região de Matopiba, no Cerrado, a savana com maior biodiversidade do mundo e uma fronteira agrícola. Foram determinadas as variáveis do modelo (fatores diretos, fatores indiretos, componentes focais e respostas) e o Nature Futures Framework foi consultado para incorporar componentes socioeconômicos e feedbacks. Cenários futuros foram desenvolvidos considerando possíveis trajetórias de fatores antropogênicos e respostas de governança que podem impactar o uso do solo na região, incluindo a possibilidade de cumprimento total do Código Florestal e a implementação da Moratória da Soja na região. O modelo conceitual e os cenários apresentados no presente trabalho podem ser úteis para melhorar a compreensão das complexas interações entre fatores antropogênicos, serviços ecossistêmicos relacionados à água e suas possíveis implicações para os sistemas naturais e sociais da região. Decisões de governança serão críticas para manter os ecossistemas da região, os serviços fornecidos por eles, a cultura e tradição das pessoas historicamente inseridas na paisagem. Em reconhecimento da dependência da humanidade em relação à natureza, destaca-se a importância de inverter a maneira como os cenários são usualmente usados. Em vez de mensurar os impactos de diferentes políticas na natureza, cenários representando os resultados desejados para biodiversidade e serviços ecossistêmicos podem ser usados para informar como políticas podem garantir a integridade dos ecossistemas no futuro.

Palavras-chave: Contribuições da natureza para as pessoas; cenários alternativos; Nature Futures Framework; política baseada na ciência; savana neotropical; Código Florestal; Moratória da soja; Matopiba.
\end{abstract}

\section{Introduction}

Human activity has degraded over $75 \%$ of Earth's land surface, driving species extinction, intensifying climate change and undermining the well-being of two fifths of humanity (Scholes et al. 2018). In 2010, land degradation cost the equivalent of about $10 \%$ of the world's annual gross product through the loss of biodiversity and benefits provided by nature (Scholes et al. 2018). Therefore, one of the main challenges nowadays is to continue producing materials to support human systems, while maintaining the functionality of the global ecosystems and the provision of ecosystem services (i.e. the benefits that humans receive from nature that are essential for human activity and well-being; MEA 2005).

Ecosystem services include the availability of freshwater, which is finite in time and space and can be impacted by anthropogenic activities. Land use/land cover change (LULC) has negative impacts on waterrelated ecosystem service provision (Spera et al. 2016). LULC and the additional impacts of climate change make access to water one of the main challenges of the 21st century (U. N. General Assembly 2015). Many regions around the world are already facing water scarcity, while the demand for water resources is increasing (Veldkamp et al. 2017).

Brazil has $12 \%$ of the planet's freshwater reserves, most of the world's rainforests and an estimated $20 \%$ of global biodiversity (FAO 2015, Brasil 2017, 2018). This wealth of Brazilian natural capital brings great responsibilities as changes occurring within its territory can affect local, regional and global environmental equilibrium (Loyola 2014, Levis et al. 2020). Agriculture is one of the sectors that most impacts this natural capital and also the strongest sector of the Brazilian economy (Almagro et al. 2017). Demand for agricultural land is one of the main pressures contributing to land degradation and the loss of biodiversity and ecosystem services in Brazil (Bustamante et al. 2019). In addition, agricultural irrigation accounts for $67 \%$ of freshwater consumption, with irrigated area covering almost 7 Mha and expected to increase (Brasil 2018).

Much agricultural expansion is occurring in the Cerrado region, the second most extensive biome in South America and the most biodiverse Neotropical savanna in the world (Sano et al. 2010). The area destined to agriculture in the Cerrado nearly tripled between 2000 and 2016 (Mansur 2017). Despite being a biodiversity hotspot, the Cerrado has already lost $46 \%$ of its coverage (Strassburg et al. 2017). Only $7 \%$ of what remains is under environmental protection, leaving approximately $40 \%$ of remaining native vegetation available for legal deforestation (Soares-Filho et al. 2014; Strassburg et al. 2017). Agricultural expansion impacts biodiversity and ecosystem services provided by the Cerrado ecosystems and draws attention to the need to implement efficient and well-planned conservation actions (Vieira et al. 2018, Resende et al. 2019).

The region of the Cerrado known as the Matopiba should be prioritised for the safeguarding of biodiversity and ecosystems services. Despite containing the largest continuous area of native vegetation of the entire Cerrado (Miranda et al. 2014), the Matopiba region has emerged as a centre of agricultural expansion and deforestation in recent decades (Sano et al. 2019, Zalles et al. 2019). Between 2002 and 2014, about $68 \%$ of the expansion occurred by suppressing native vegetation (Garcia \& Filho 2018). In 2017 the region was responsible for $11 \%$ of Brazil's soy production and as agricultural expansion is predicted to continue, demand for water in the Matopiba is expected to increase considerably (Ferrarini et al. 2019, de Barros \& Stege 2019). Water scarcity is already a problem in this region and is expected to worsen as environmental conditions become warmer and drier according to climate projections 
(Brasil 2018). Feedbacks between land use/land cover and climate change could also affect rainfall amounts and patterns, threatening the sustainability of agricultural production (Spera et al. 2016) and intensifying social conflicts over land and water.

Maintaining biodiversity and ecosystem services into the long term poses a great challenge. Policy responses to this challenge at the local and global scale may benefit from the use of integrated models that describe the drivers of change and their impacts on natural resources (Janse et al. 2015). Understanding and modelling the drivers of change, pressures and their dynamic links with biodiversity, ecosystem services and human well-being is thus essential to integrate science, society and stakeholders (Díaz et al. 2015). Models may aid the development of well-informed, science-based policies that explicitly consider biodiversity and ecosystem services, by evaluating alternative scenarios of policy options and their consequences for socio-ecological systems (Janse et al. 2015). Research to improve the sophistication of scenario modelling is necessary to the advancement of environmental policy that is capable of guaranteeing biodiversity and ecosystem services into the future.

Using the Matopiba region of Brazil as a case study this article has two main aims: i) to describe the development of a conceptual model that shows how anthropogenic drivers impact water-related ecosystem services, and ii) to develop future scenarios that consider the main governance options relevant to the study area. In order to develop this conceptual model and determine possible future scenarios, a Nature Futures Framework approach was used, considering values associated with water-related ecosystem services that encompass social (e.g. economic and utilitarian), cultural (e.g. traditional and Indigenous identities) and intrinsic values. These three ways of distinguishing the value of nature reflect the multiple ways that water-related ecosystem services can be understood and valued by diverse stakeholders in the Matopiba region. Whilst no actual modelling was undertaken in this study, the conceptual model and future scenarios presented here may be used to guide future studies that aim at scenario modelling in the region.

\section{Material and Methods}

\section{Study Area}

The study focused on the Matopiba region in the northern part of the Brazilian Cerrado that encompasses portions of the states of Maranhão, Tocantins, Piauí and Bahia (Miranda et al. 2014; Figure 1). The region covers approximately 73 million hectares ( $~ 8 \%$ of the Brazilian territory) originally composed by different types of vegetation, including grassland, shrubland, savanna and forest ecosystems (Miranda et al. 2014). Approximately 17\% of the Matopiba is covered by protected areas, including those set for strict protection (IUCN categories I to III), sustainable use (IV to VI) and Indigenous lands (Embrapa 2015). The region's average annual temperature is above $25^{\circ} \mathrm{C}$ with an annual rainfall of between $1000 \mathrm{~mm}$ and $1900 \mathrm{~mm}$ (Alvares et al. 2013). In recent years the native vegetation of the Matopiba has been rapidly converted to agricultural activities (Figure 2), mainly mechanised soybean plantation (e.g. soy production in the region increased by $253 \%$ between 2000 and 2014; Carneiro \& Costa 2016). Following this trend, Matopiba has become one of the last large-scale agricultural frontiers in the world (OECD/FAO 2015). In the coming decade Brazil is expected to become the world's largest producer of soybean (Cattelan \& Dall'Agnol 2018) and agricultural expansion in the Matopiba is expected to continue at

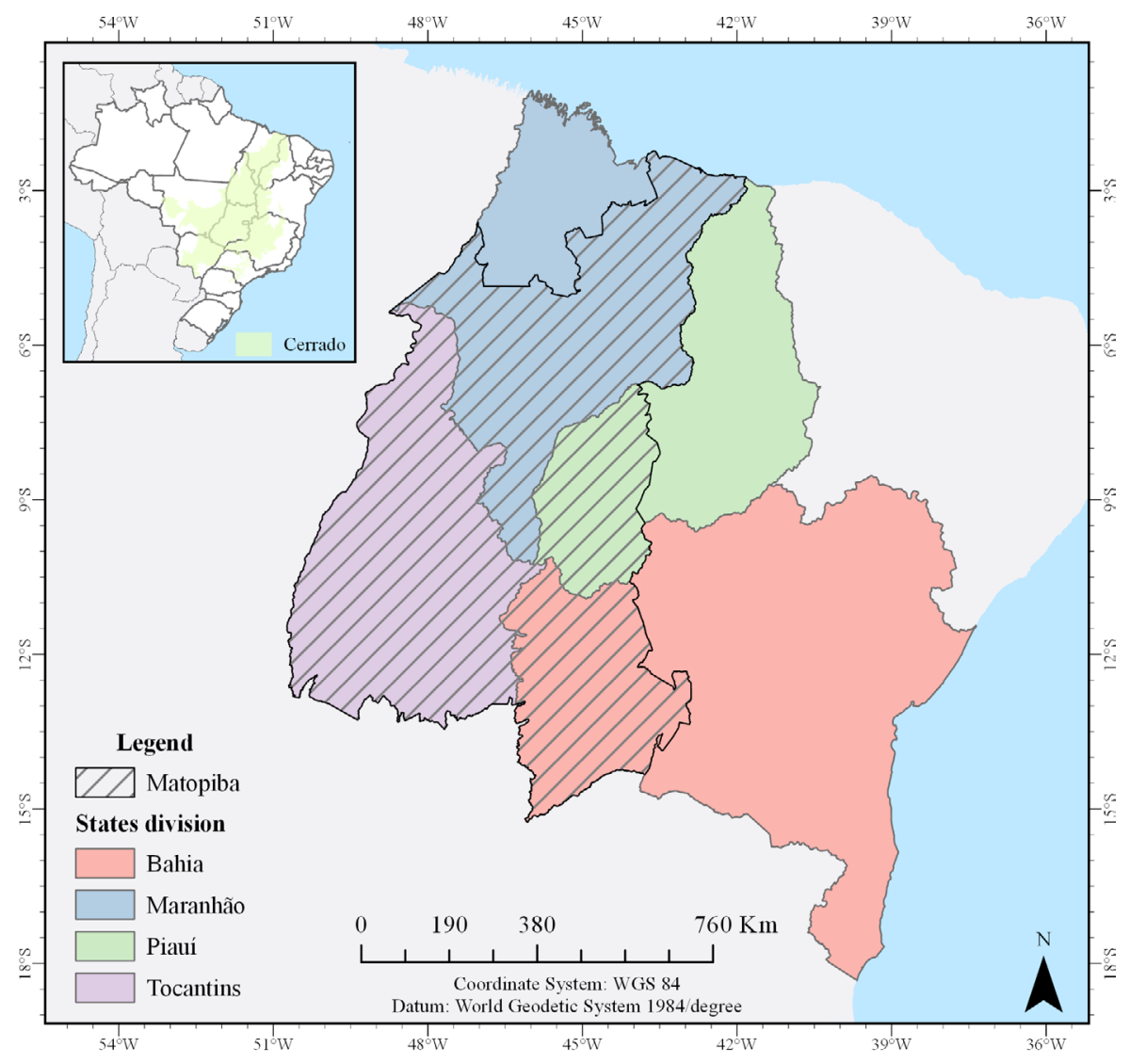

Figure 1. Location of the Matopiba region. 

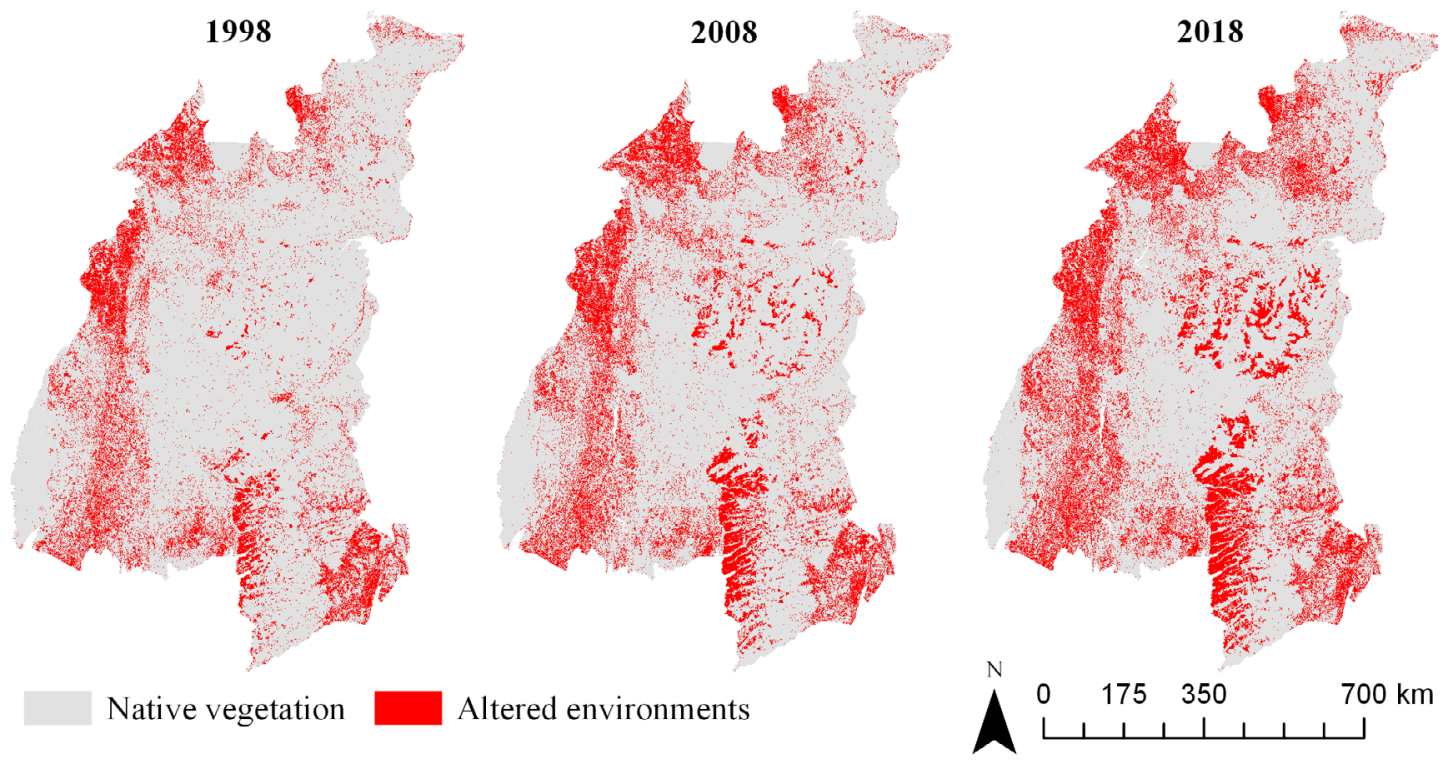

Source: Project MapBiomas - Collection 4 of Brazilian Land Cover \& Use Map Series.

Figure 2. Land use/land cover changes in the Matopiba region over recent decades. Native vegetation includes remnants of forest, savanna and grassland ecosystems, while altered environments include mainly pasture and agricultural areas.

a rapid pace due to land availability, land costs, high productivity potential and continued demand for this commodity.

\section{Drawing a conceptual model}

A conceptual model of a social-ecological system can be defined as 'a concise summary in words or pictures of relationships between people and nature' (Díaz et al. 2015, p3). Models integrate key social and ecological components, and represent, in a simplified way, the interrelations between components. Drawing a conceptual model can be used to identify the primary components of interest within a system and the interrelationships that occur between those components, with the intention of identifying how changes in drivers may impact other components of the system (Díaz et al. 2015).

The conceptual model for the Matopiba region was developed following the guidance of prominent researchers during the scientific course "São Paulo School of Advanced Science on Scenarios and Modelling on Biodiversity and Ecosystem Services to Support Human Well-Being", which was held in São Pedro, São Paulo, Brazil, during two weeks in July/2019. These researchers presented different types of conceptual frameworks, scenarios and models associated with biodiversity, ecosystem services and human well-being that informed the construction of the model presented in this study. Throughout the event, findings were presented to all participants ( $\sim 90$ early-career researchers from different countries, cultures, and theoretical backgrounds) and ideas and suggestions were shared to improve our approach. Instructions and feedback were complemented by the authors' knowledge about the Matopiba region and literature review.

The focus of the conceptual model (presented in the results section) developed in this study was to assess the impact of agricultural expansion on nature, mainly on water-related ecosystem services and biodiversity. The development of the approach considered indirect drivers (i.e. underlying causes of change that are generated outside the ecosystem in question; Díaz et al. 2015); direct drivers (i.e. natural or anthropogenic factors that affect nature directly; Díaz et al. 2015); focal components (i.e. the main components of the system that are selected in order to measure the effects of changing drivers); and responses (i.e. the outcomes caused by the changes in the focal components). The links between each variable, including feedbacks among them, were investigated.

\section{Incorporating the Nature Futures Framework}

The Nature Futures Framework was used to identify how waterrelated ecosystem services could be valued according to nature perspectives, which reflect how different actors may perceive and relate to nature. The Nature Futures Framework was developed by the Intergovernmental Science-Policy Platform on Biodiversity and Ecosystem Services (IPBES) and considers the different values and relationships that people have with nature, including cross-scale dynamics and socio-ecological feedbacks (Lundquist et al. 2017). The framework provides a methodology to incorporate different ways of valuing nature into decision-making (Schoolenberg et al. 2018). The nature for nature lens recognises the value of the preservation of nature's processes and the intrinsic value of natural systems, without human intervention. Through the perspective of nature for people, the value of nature is connected to the utilitarian functions of ecosystems. The nature as culture perspective recognises the integration of human and natural systems, in which humans are an integral part of nature and its functions.

\section{Future scenario development}

Exploratory scenarios were developed aiming to examine a range of potential trajectories of direct drivers for the Matopiba region (e.g. IPBES 2016). Specifically, alternative future scenarios were proposed, focusing on variations in the implementation of environmental policies (i.e. Forest Code, Soy Moratorium, management of protected areas/ Indigenous lands) and international demand for soybeans, as presented below and summarised in Table 1. These components were included in the scenarios because they contribute to determine future LULC 
in the Matopiba region. Actual modelling was beyond the scope of this study, nonetheless these scenarios were useful to explore possible implications of political decisions for multiple socio-ecological variables. All five scenarios considered that climate change would occur following a unique climate change projection (e.g. the most probable climate change scenario based on current predictions; IPCC 2014). Using the same climate change projection maintains comparability among the five proposed scenarios and isolates the influence of LULC. Thus, five alternative future scenarios were proposed:

1) Business as usual scenario: considers that policies and other drivers of change that influence LULC in the region would not be changed and agriculture would continue to expand at current trends. This scenario considers that part of agricultural expansion implies illegal deforestation, in accordance with current rates and patterns. Indeed, compared to other regions such as the Amazon, environmental regulations in the Matopiba are less strict with fewer policies to prevent and monitor environmental degradation (Calmon 2017).

2) Forest Code scenario: considers that agricultural expansion will continue to occur, but in compliance with the Forest Code (formally recognised as the Native Vegetation Protection Law; Law $n^{\circ} 12651 / 2012$ ), the main piece of Brazilian environmental legislation that guides LULC on private rural properties (Brancalion et al. 2016). The Forest Code defines the areas within private rural properties in which native vegetation must be maintained or restored: the Permanent Preservation Area (PPA) and the Legal Reserve (LR). PPA is comprised mainly of the margins of watercourses and areas with steep slopes and hilltops, aiming to conserve water resources and maintain geological stability within rural properties. The LR is an area within a rural property aimed at ensuring the sustainable use of natural resources, the conservation and rehabilitation of ecological processes, and the conservation of biodiversity. In the Matopiba region, landowners are obliged to set aside $20-35 \%$ of their property as LR (the highest percentage valid for properties that occur within the boundary of the Legal Amazon; Zakia \& Pinto 2013). This scenario considers that PPA and LR in the Matopiba region would be properly maintained in accordance with the Forest Code. As a consequence, there will be no illegal deforestation, but still $40 \%$ of the native vegetation could be legally converted to agriculture (Soares-Filho et al. 2014).

3) Soy Moratorium scenario: considers that the Soy Moratorium would be implemented in the region, thus avoiding the conversion of native vegetation into soybean plantations. The Soy Moratorium is a zero-deforestation voluntary agreement signed by major players in the soybean production chain and implemented in the Brazilian Amazon (Gibbs et al. 2015). Several studies have shown that the Soy Moratorium has been effective in preventing conversion of native vegetation to soybean fields in the Amazon (Nepstad et al. 2014, Kastens et al. 2017, Gollnow et al. 2018). However, leakage to the Cerrado region may have occurred (Latawiec et al. 2015). Implementing the Soy Moratorium in the Cerrado would be particularly significant to prevent further deforestation in the Matopiba, as approximately $40 \%$ of soybean expansion in this region so far has occurred over native vegetation areas (Gibbs et al. 2015).

4) Utopia scenario: considers that global consumption of agricultural commodities will no longer increase (Schneider et al. 2010). Therefore, agricultural area would not expand in the Matopiba. In addition, Forest Code will be properly enforced and the network of protected areas would be expanded to $50 \%$ of the Matopiba's area, following the HalfEarth project proposal (Wilson 2016). Protected areas are effective in preventing deforestation and have a major role in protecting the remaining natural vegetation in the Cerrado (Carranza et al. 2014, Paiva et al. 2015, Brum et al. 2019). This scenario is based on the concepts discussed by Scarano (2019) about "deep" sustainability, which is characterised by "a world where people and nature live in full harmony by considering both long and short-term perspectives" (Scarano 2019, p. 53). Whilst this scenario represents a future that diverges from much current experience, it is important to identify the kind of future that humanity should strive for and the different pathways to achieve that future (Rosa et al. 2017).

5) Agribusiness scenario: considers a softening of national environmental policies according to bills presented by the current federal government. It considers the approval of bill n. 2362/19, which removes the requirement for LR within all private properties in Brazil (see

Table 1. Description of the five alternative scenarios.

\begin{tabular}{|c|c|c|c|c|c|}
\hline & $\begin{array}{l}\text { Business as usual } \\
\text { scenario }\end{array}$ & $\begin{array}{l}\text { Forest Code } \\
\text { scenario }\end{array}$ & $\begin{array}{l}\text { Soy Moratorium } \\
\text { scenario }\end{array}$ & $\begin{array}{c}\text { Utopia } \\
\text { scenario }\end{array}$ & $\begin{array}{l}\text { Agribusiness } \\
\text { scenario }\end{array}$ \\
\hline Forest Code & $\begin{array}{l}\text { No changes in } \\
\text { current enforcement }\end{array}$ & Full enforcement & Full enforcement & Full enforcement & $\begin{array}{l}\text { Full enforcement, } \\
\text { however extinction of } \\
\text { Legal Reserves }\end{array}$ \\
\hline Soy Moratorium & No implementation & No implementation & Implementation & Not applicable & No implementation \\
\hline $\begin{array}{l}\text { Protected areas/ } \\
\text { Indigenous } \\
\text { lands }\end{array}$ & $\begin{array}{l}\text { No changes in the } \\
\text { current coverage and } \\
\text { management }\end{array}$ & $\begin{array}{l}\text { No changes in the } \\
\text { current coverage and } \\
\text { management }\end{array}$ & $\begin{array}{l}\text { No changes in the } \\
\text { current coverage and } \\
\text { management }\end{array}$ & $\begin{array}{l}\text { Expansion of PA/ } \\
\text { IL to } 50 \% \text { of the } \\
\text { region's area }\end{array}$ & $\begin{array}{l}\text { Legal permission to } \\
\text { expand agriculture } \\
\text { inside Indigenous land }\end{array}$ \\
\hline Agriculture & $\begin{array}{l}\text { Agricultural } \\
\text { expansion under } \\
\text { current trends }\end{array}$ & $\begin{array}{l}\text { Agricultural } \\
\text { expansion in } \\
\text { accordance with the } \\
\text { Forest Code }\end{array}$ & $\begin{array}{c}\text { Agricultural expansion } \\
\text { in accordance with the } \\
\text { Forest Code and Soy } \\
\text { Moratorium }\end{array}$ & $\begin{array}{c}\text { No further } \\
\text { expansion of } \\
\text { agricultural areas }\end{array}$ & $\begin{array}{l}\text { Strong agricultural } \\
\text { expansion due } \\
\text { to weakening of } \\
\text { environmental policy }\end{array}$ \\
\hline $\begin{array}{l}\text { International } \\
\text { demand for } \\
\text { soybeans }\end{array}$ & $\begin{array}{l}\text { Increasing demand, } \\
\text { following the current } \\
\text { trends }\end{array}$ & $\begin{array}{l}\text { Increasing demand, } \\
\text { following the current } \\
\text { trends }\end{array}$ & $\begin{array}{l}\text { Increasing demand, } \\
\text { following the current } \\
\text { trends }\end{array}$ & $\begin{array}{l}\text { No changes in the } \\
\text { current demand }\end{array}$ & $\begin{array}{l}\text { Increasing demand, } \\
\text { following the current } \\
\text { trends }\end{array}$ \\
\hline
\end{tabular}


Metzger et al. 2019). In addition, this scenario considers that protections for Indigenous lands would be modified to allow the legal expansion of agriculture within Indigenous lands, considered in bill n. 191/20.

\section{Results}

\section{The conceptual model}

The conceptual model is presented in Figure 3. The focal components selected were water quality and quantity, a choice that reflects the critical role that water-related ecosystem services play in the development of the study region (Garcia \& Filho 2018). The model includes three indirect drivers (commodity market, governance and technology) which affect the direct drivers (climate change and LULC). Commodity markets generate pressure on natural systems through the demand for primary resources, fostering or discouraging agricultural expansion (Marques et al. 2019). Governance (i.e. trends in the implementation and enforcement of regulation and legislation including the Forest Code, Soy Moratorium and establishment or degazetting of protected areas) can either intensify climate change and LULC or promote conservation through land protection and regulation of land use. Technological advancements might foster the transition from small-scale agriculture to mechanised agriculture, requiring the use of great extensions of land, along with the implementation of irrigation systems and the intensive use of pesticides and agrochemicals. Conversely, technological advances in agriculture can create the sustainable intensification of agriculture, increasing productivity such that pressure for expansion is eradicated (Latawiec et al. 2015).

Feedbacks among climate change and LULC were identified in the conceptual model. Climate projections for the region show a trend for increased mean temperature, decreased daily and annual precipitation and lower atmospheric humidity, leading to even dryer conditions and, in the long term, desertification (Marengo \& Bernasconi 2014). These expected changes can lead to the unsuitability of areas for growing crops, displacing agricultural expansion in response to the changing climate (FAO 2016). Moreover, as the conversion of native Cerrado vegetation by agriculture decreases the water balance, LULC might affect precipitation in the region (e.g. Spera et al. 2016). LULC also modifies carbon stocks in vegetation and soil, contributing to climate change. Climate change and LULC in turn affect water quality and water quantity, the model's focal components (Nobre et al. 2020). These changes might negatively affect agricultural production, water catchment runoff and ecosystem services (Marengo \& Bernasconi 2014).

Climate change can affect water quality and quantity in several ways, including increased temperatures, seasonal variability of precipitation, and evapotranspiration or decreased annual rainfall (Sun et al. 2008; Carpenter et al. 2011; Nunes et al. 2017). Higher water temperatures and less precipitation can lead to a reduction in water yield, especially during low flow seasons, thus affecting the timing and inflow of water to reservoirs (De Lucena et al. 2009; Bangash et al. 2013; Neupane et al. 2015; Van Vliet et al. 2016). Seasonal changes in precipitation can lead to greater erosion and nutrient export, thus causing siltation of reservoirs (Nunes et al. 2017). Increased nutrient loading and warmer water temperatures, can favour the proliferation of blooms of cyanobacteria (Paerl \& Paul 2012; Bonilla et al. 2016) and threaten the persistence of aquatic organisms due to less dissolved oxygen and increased pollutant load (Carpenter et al. 2011). As a result, the provision of drinking and irrigation water, habitat for biodiversity, and hydropower generation can be hampered by changes in water quality and quantity caused by the adverse effects of climate change. The impairment of freshwater resources can cause local land conflicts by emphasising inequalities and forcing migration (Reuveny et al. 2007; Scheffran \& Battaglini 2011).

LULC might also have several consequences on water quality and quantity (Vitousek 1997; Marques et al. 2019). For

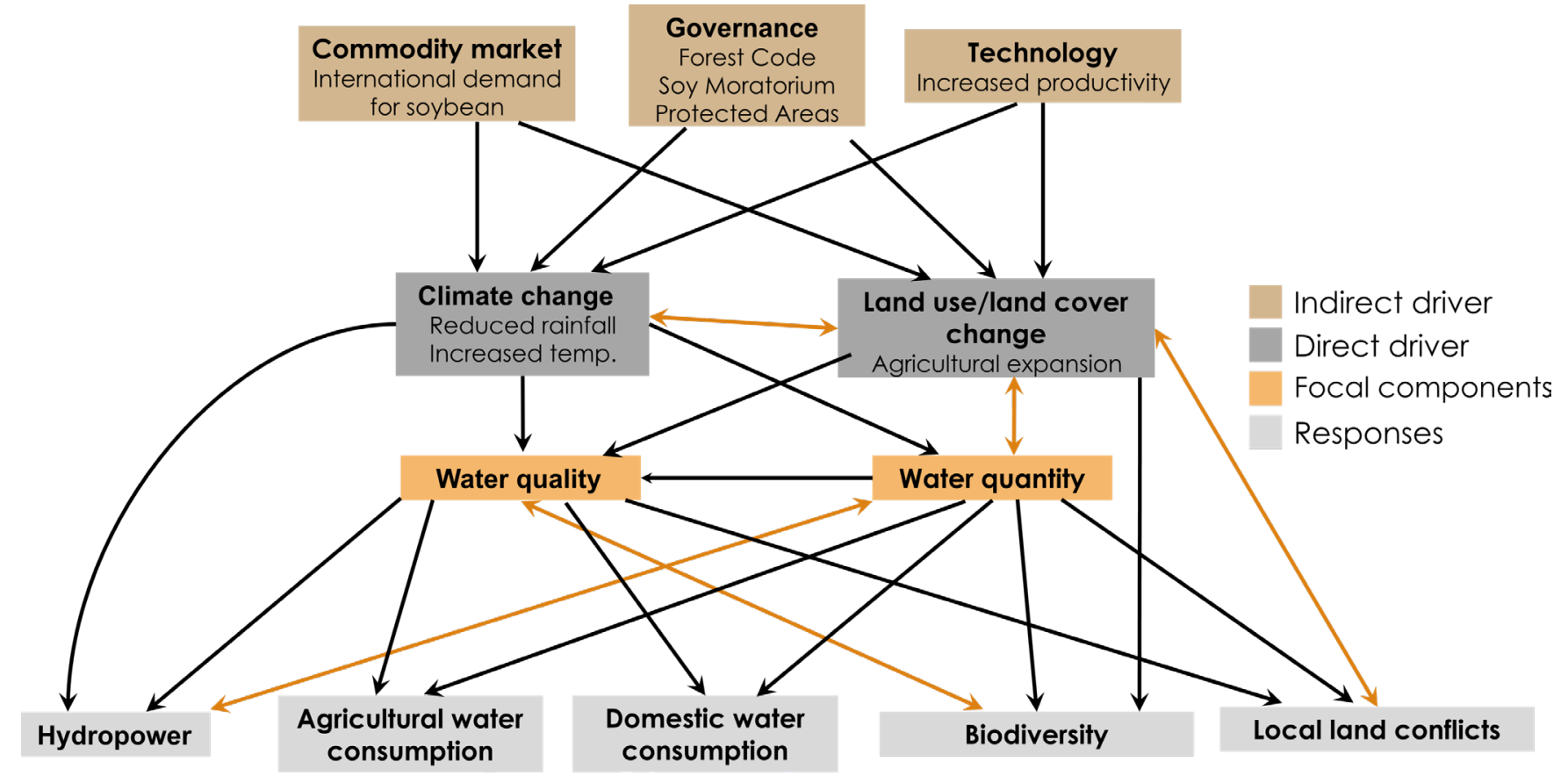

Figure 3. Conceptual model describing the focal components, drivers, and responses related to water quality and quantity in the Matopiba region of Brazil. Arrows represent possible relationships among variables. Feedback relationships are represented by orange arrows. 
example, the conversion of natural habitats to agriculture might alter the patterns of evapotranspiration, runoff and groundwater recharge (Sun et al. 2008; Carpenter et al. 2011; Nunes et al. 2017). Fertilisers and other agrochemicals are sources of nutrients and other pollutants; therefore, soil erosion and runoff contribute to exporting them to water (Schilling et al. 2008). Nutrient enrichment from agricultural sources can favour the proliferation of cyanobacterial blooms, affecting domestic water consumption and aquatic biodiversity (Paerl \& Otten 2013; Doubek et al. 2015). In addition, LULC might be associated with the increased water demand for irrigation and hydropower generation, which is met through increased diversions and impoundments (Vitousek et al. 1997). Expansion of crops can also push smallholders and Indigenous and traditional communities to marginal lands with scarce resources, which can lead to conflicts and disputes (Mbonile 2005; Sauer 2018).

Therefore, the two direct drivers (LULC and climate change) can drive reductions in water quality and quantity, affecting water potability and aquatic biodiversity and potentially causing conflicts related to the availability of clean water. Changes in water quantity might also affect water quality. Changes in both parameters (water quality and quantity) may impact human activities (i.e. hydropower, agricultural and domestic water consumption), biodiversity and land conflicts, which were identified as responses in the conceptual model.

\section{The Nature Futures Framework perspective}

Considering that the region encompasses different types of social groups, including Indigenous and traditional communities, smallholder family farmers and more recently large-scale agribusiness farmers, the potential values associated with a healthy hydric system could vary a lot. Thus, different values could be associated with the water-related ecosystem services included in the conceptual model (Figure 4). In terms of the utilitarian perspective of nature for society, water-related ecosystem services can be valued for the energy offered through hydropower, water for agricultural irrigation and domestic use and the tourism opportunities provided by the river system. When viewing nature as having intrinsic value through the nature for nature lens, the important aspects include the maintenance of ecosystem function and biodiversity and the regulation of the water cycle. Nature as culture provides a perspective in which water quality and quantity can be valued as providing opportunities for learning and inspiration, maintaining culturally important species and supporting the identities of people with a long history in the region. Clashes in ways of understanding and valuing nature by actors coexisting and utilising the same land, coupled with unequal access to resources can lead to conflict for land and water.

\section{Predicted outcomes of future scenarios}

The five scenarios proposed in the present study could generate remarkably different outcomes in terms of the rate of agricultural expansion, water quality and quantity, land and water conflicts and biodiversity. Whilst performing scenario modelling was not within the scope of this article, it was possible to predict results that may arise from each scenario based on a literature review and authors' knowledge of Brazilian environmental policies. The predicted outcomes of each scenario are described below and trends summarised in Figure 5.

In the "Business as usual" scenario, the increased demand for water and runoff of agricultural inputs could impair biodiversity and the provision of water-related ecosystem services. It is expected that poor compliance with the Forest Code would result in high levels of deforestation (Roriz et al. 2017, Soterroni et al. 2018). Soterroni and colleagues (2018) suggested that weak enforcement of the Forest Code in Brazil would result in deforestation rates similar to those of a scenario without this mechanism in place. Agricultural expansion in the Matopiba region would lead to high erosion rates, which, beyond impacting on river systems, can affect agricultural productivity (Gomes et al. 2019). Agricultural expansion may exacerbate social inequality as natural and economic resources are unevenly distributed among the agribusiness sector and Indigenous and traditional communities and other regional actors. Land and water conflicts would be expected to increase.

In the "Forest Code" scenario, the rate of LULC would probably decrease due to an absence of illegal deforestation, leading to a slight increase in the biodiversity conservation and provision of water-related

\section{Nature for nature}

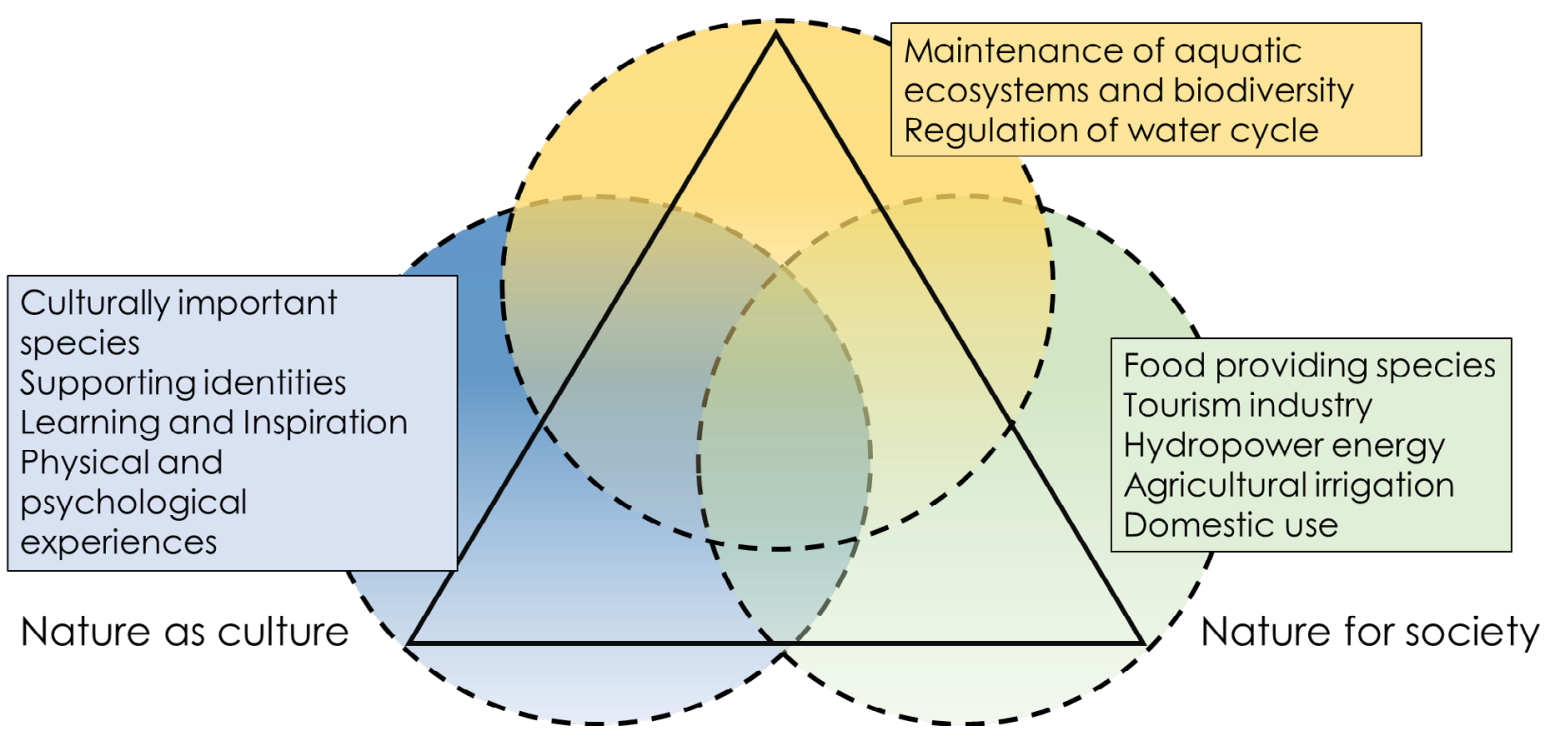

Figure 4. Values of nature according to different perspectives of water-related ecosystem services in the Matopiba region. 
ecosystem services when compared to the "Business as usual" scenario. However, in the Matopiba region there is a surplus of native vegetation that can be legally cleared, so even with Forest Code enforcement full benefits for water security and biodiversity may not be realised (Vieira et al. 2018). Moreover, the riparian widths for rivers introduced by the Forest Code, after revisions approved in 2012, may be insufficient to protect water quality (Valera et al. 2019). Under this scenario, conflicts for land and water may still occur. Even when undertaken in compliance with the Forest Code the expansion of agricultural activities may impact on livelihoods and access to resources of other regional actors.

In the "Soy Moratorium" scenario, the expansion of soybean production would not imply the conversion of native vegetation. Around $40 \%$ of the remaining Cerrado native vegetation could be legally converted to agriculture in the absence of the Soy Moratorium (Strassburg et al. 2017), so its implementation is an urgent matter. The Moratorium could create great benefits for the conservation of Matopiba, as $86 \%$ of soy expansion is expected to occur within the Cerrado region until 2050 (Soterroni et al. 2019). The native vegetation maintained through the implementation of the Soy Moratorium could reduce the rate of soil erosion, improve water quality indicators, and increase biodiversity conservation when compared to the "Business as usual" scenario. Under this scenario LULC would be reduced, generating less land and water conflicts

In the "Utopia" scenario the expansion of agricultural area will be very low (or even zero) due to the reduction of international demand for soybeans and environmental policies, thus the provision of waterrelated ecosystem services and biodiversity conservation would improve significantly compared to the "Business as usual" scenario. The enforcement of the Forest Code and increase in protected area would result in a larger proportion of land with native vegetation, contributing to the provision of water-related services. By allowing increased water infiltration and storage, natural vegetation will secure water supply in different seasons. Landscape composition is related to surface water quality, and several studies indicate that larger percentages of forest in the watershed are correlated with better water quality (Qiu \& Turner 2015, Huang et al. 2016). Following strong changes in the development pattern of the region, a reduction in land and water conflicts between agribusiness, Indigenous and traditional peoples and other stakeholders could be expected.

In the "Agribusiness" scenario, the softening of national environmental policies could lead to a higher rate of LULC than seen in the "Business as usual" scenario. Agriculture could expand extensively in Matopiba, including into Indigenous territories. If LRs were revoked, about $29 \%$ of the remaining vegetation in Brazil could be legally cleared, and the Cerrado could be reduced to only $13 \%$ of its original extension of native vegetation cover (Metzger et al. 2019). As a result, biodiversity and ecosystem services would be drastically affected due to the large loss of natural vegetation from private lands (Metzger et al. 2019). Without natural vegetation, unsustainable agriculture practices would generate high sediment loads, nutrients and other pollutants that would enter water bodies. Moreover, land and water conflicts may be exacerbated due to unregulated agricultural expansion in the absence of robust environmental policies, potentially affecting Indigenous and traditional livelihoods and well-being.

\section{Discussion}

The reduction of water availability due to the combination of LULC and climate change, along with an accompanying increase in demand for water resources for agriculture amongst other uses is causing severe competition for this resource in the Matopiba region (Pousa et al. 2019). The conceptual model proposed in the present study might be useful to improve understanding of the complex interaction among anthropogenic drivers, water-related ecosystem services and their multiple potential repercussions for natural and social systems. In turn, the alternative future scenarios described here demonstrate that governance decisions will be critical to maintaining the Cerrado biome, the services it provides and the culture and tradition of the people historically embedded in the landscape.
Direction of change

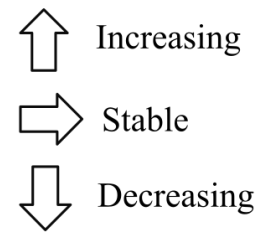

Intensity of change

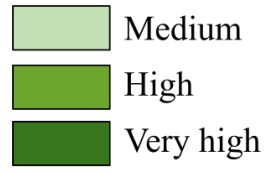

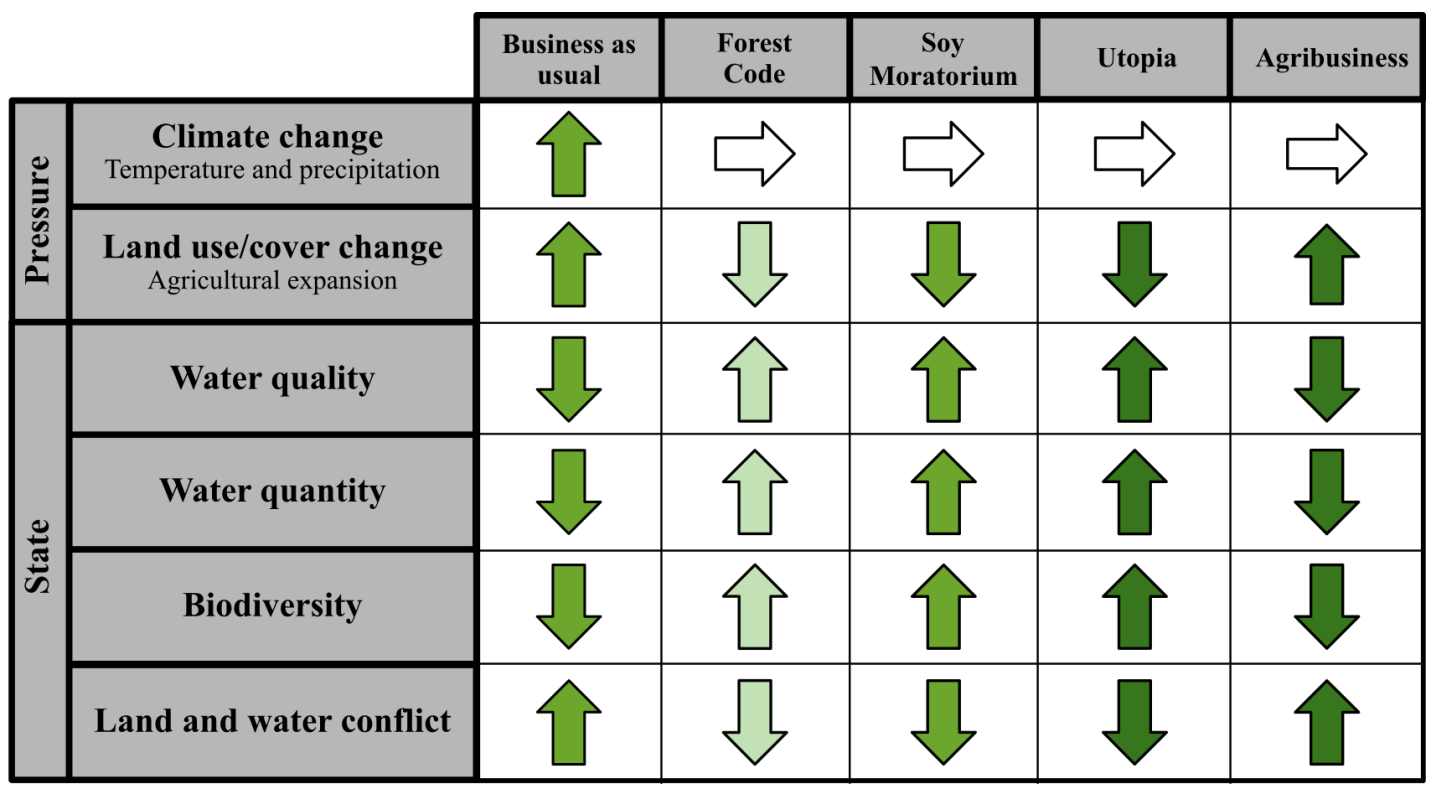

Figure 5. Predicted trends in changes in pressures and state under each scenario. 
The use of scenario modelling delivers decision-makers a window into the future, to observe the outcomes for a range of socioenvironmental indicators that have implications for human wellbeing (Nicholson et al. 2019). In this case study, both the "Business as usual" and "Agribusiness" scenarios imply drastic reductions in the provision of water-related ecosystem services, biodiversity and also have impacts on regional stakeholders such as Indigenous groups and traditional communities. The "Forest Code" and "Soy Moratorium" scenarios generate positive outcomes for water-related ecosystem services and conflict reduction, however not to the same extent as the "Utopia" scenario. According to these hypothesised predictions, governance measures including Forest Code enforcement coupled with the implementation of the Soy Moratorium are minimum requirements for guaranteeing the protection of Cerrado ecosystems and associated ecosystem services and biodiversity.

\section{Challenges in incorporating complex realities into models}

The process of creating a conceptual model to assess the impacts of direct and indirect drivers on biodiversity and ecosystem services poses several challenges. Primarily there is the intrinsic limitation of all conceptual models to represent complex realities, given the impossibility of the inclusion of all variables and all possible relationships in one single model. Further challenges arise in the inclusion of variables that are difficult to measure or quantify, such as well-being or cultural identity. Many studies emphasise that the notion of value should not be restricted to mere instrumental values but embrace a larger range of values, including those related to supporting identities and culture (e.g. Jax 2019). Cultural services can be intangible and may include spiritual and cultural identification, recreation opportunities or heritage values (Bray et al. 2019). Despite the challenges of including multiple ways of valuing nature into models this is essential to improve understanding of the complex relationships and feedbacks that may occur.

It is important to recognise that land and water-related conflicts represent just one part of the many issues that threaten human well-being; there is a huge knowledge gap on how to incorporate human well-being indicators into research and modelling (Pires et al. 2018). In the Matopiba region, the well-being of traditional and Indigenous local populations suffers as they struggle with land grabbing and water conflicts related to soybean agriculture expansion. The land rights of traditional and Indigenous groups are extremely difficult to express in data that can be incorporated into scenario modelling because land tenure in the region is mostly informal, based on customary and continuous land occupation over generations (Pitta \& Vega 2017). Furthermore, already existing conditions of land-expropriation and population expulsion driven by large-scale agricultural expansion are prone to aggravate under climate change effects such as water scarcity (Pitta \& Vega, 2017). This may directly affect Indigenous and smallholder communities by forcing them to diversify their livelihoods or migrate and abandon their original territory, implying deep cultural consequences that cannot be measured by indices such as Gross Domestic Product (GDP). Careful considerations need to be made when attempting to include human well-being to models and in terms of deciding what types of indicators should be used. Alternative indicators that explicitly include natural and social aspects should be fostered, using as a basis examples such as the Human Development Index (HDI), Multidimensional Poverty Index, Inequality-adjusted
Human Development Index, Gender Inequality Index (UNDP, 2018) or the Genuine Progress Indicator (Andrade \& Garcia 2015).

\section{Using scenarios to guarantee ecosystem service provision}

Whilst the incorporation of the diversity of nature's values into scenario modelling is still incipient, it is an endeavour that can improve the sophistication of our responses to complex problems. In this way, the Nature Futures Framework aims at informing the development of positive scenarios, where humans and nature thrive together, addressing the multiple visions and values of nature (Rosa et al. 2017). A challenge faced throughout the elaboration of this work was how to develop scenarios that represent a future that humanity could strive for, aligned with the Nature Futures Framework. Developing the "Utopia" scenario was an exercise that reflected this, with a focus on valuing nature so as to ensure the provision of ecosystem values across all perspectives into the future. Indeed, with the application of sustainable agricultural practices, production from the region could remain the same or increase, even whilst conservation measures were enforced. The "Utopia" scenario determined nature-centred objectives and then established the changes in governance needed to achieve them, rather than supposing policy changes and analysing their impacts. When the focus is placed on maintaining biodiversity and ecosystem services it reveals the drastic policy and societal changes that need to be made. Nature conservation must be central to policy formation, including the creation of policy options that represent a future that society should aim towards, where human systems continue to be supported by the services provided by natural systems (Rosa et al. 2017).

\section{Conclusion}

With critical ecological thresholds being crossed, the decisions that are taken by policy-makers in the coming decade may cause or avoid irreversible impacts for future generations, either placing in jeopardy the natural systems on which humanity depends or guaranteeing their survival. The elaboration of scenarios that intend to deliver the biodiversity and ecosystem services outcomes necessary to maintain Earth's life support systems allows insights into the opportunities and barriers that exist in defining policy, and more broadly, in transforming society to a model of existence that occurs within the limits determined by our finite Earth. As such, this study intended to shine a light on the possible pathways available to prevent the destruction of the Cerrado biome for short-term gain and provide insights into how the incorporation of the multiple values of nature can inform spatial planning and policy responses to guarantee the future of the world's most biodiverse savanna.

\section{Acknowledgements}

This study is the result of the authors' participation in the "São Paulo School of Advanced Science on Scenarios and Modelling on Biodiversity and Ecosystem Services to Support Human Well-Being" held in São Pedro-SP, Brazil, from 01 to 14 July 2019 (https://scenariosbes.wixsite. com/spsas-scenarios). We are grateful to the organizers, professors, speakers, tutors and participants for the knowledge and experience shared throughout the event. We also thank Guilherme R. Lima and Roberta Z. Cantinho for their valuable contributions to the study. This 
study was financed in part by the Coordenação de Aperfeiçoamento de Pessoal de Nível Superior - Brasil (CAPES) - Finance Code 001, and by the Conselho Nacional de Desenvolvimento Científico e Tecnológico (CNPq). RLGN is supported by CAPES (Process 88882.181100/201701). FMR, LMBC are supported by CNPq (Process $158733 / 2018-5$ and 140337/2017-2, respectively).

\section{Author Contributions}

Fernando de Moura Resende: Substantial contribution in the concept and design of the study; Contribution to data collection; Contribution to data analysis and interpretation; Contribution to manuscript preparation; Contribution to critical revision, adding intellectual content.

Lara A. Cornejo Denman: Substantial contribution in the concept and design of the study; Contribution to data collection; Contribution to data analysis and interpretation; Contribution to manuscript preparation; Contribution to critical revision, adding intellectual content.

Gracie Verde Selva: Substantial contribution in the concept and design of the study; Contribution to data collection; Contribution to data analysis and interpretation; Contribution to manuscript preparation; Contribution to critical revision, adding intellectual content.

Ligia Maria Barrios Campanhão: Substantial contribution in the concept and design of the study; Contribution to data collection; Contribution to data analysis and interpretation; Contribution to manuscript preparation; Contribution to critical revision, adding intellectual content.

Regina Lúcia Guimarães Nobre: Substantial contribution in the concept and design of the study; Contribution to data collection; Contribution to data analysis and interpretation; Contribution to manuscript preparation; Contribution to critical revision, adding intellectual content.

Yohana Gisell Jimenez: Substantial contribution in the concept and design of the study; Contribution to data collection; Contribution to data analysis and interpretation; Contribution to manuscript preparation; Contribution to critical revision, adding intellectual content.

Edberto Moura Lima: Substantial contribution in the concept and design of the study; Contribution to data collection; Contribution to data analysis and interpretation; Contribution to manuscript preparation; Contribution to critical revision, adding intellectual content.

Julia Niemeyer: Substantial contribution in the concept and design of the study; Contribution to data collection; Contribution to data analysis and interpretation; Contribution to manuscript preparation; Contribution to critical revision, adding intellectual content.

\section{Conflicts of Interest}

The authors declare that they have no conflict of interest related to the publication of this manuscript.

\section{References}

ALMAGRO, A., OLIVEIRA, P.T.S., NEARING, M.A. \& HAGEMANN, S. 2017. Projected climate change impacts in rainfall erosivity over Brazil. Sci. Rep. 7(1):1-12.

ALVARES, C.A., STAPE, J.L., SENTELHAS, P.C., DE MORAES GONÇALVES, J.L. \& SPAROVEK, G. 2013. Köppen's climate classification map for Brazil. Meteorol. Z. 22(6):711-728.
ANDRADE, D.C., GARCIA, J.R., 2015. Estimating the Genuine Progress Indicator (GPI) for Brazil from 1970 to 2010. Ecol. Econ. 118, 49-56.

BANGASH, R.F., PASSUELLO, A., SANCHEZ-CANALES, M., TERRADO, M., LÓPEZ, A., ELORZA, F.J., ZIV, G., ACUÑA, V., SCHUHMACHER, M. 2013. Ecosystem services in Mediterranean river basin: Climate change impact on water provisioning and erosion control. Sci. Total Environ. 458-460:246-255. https://doi.org/10.1016/j.scitotenv.2013.04.025

BONILLA S., GONZÁLEZ-PIANA M., SOARES M.C.S., HUSZAR V.L.M., BECKER V., SOMMA A., et al. 2016. The success of the cyanobacterium Cylindrospermopsis raciborskii in freshwaters is enhanced by the combined effects of light intensity and temperature. Journal of Limnology 75, 606-617. https:// 10.4081/jlimnol.2016.1479

BRANCALION, P.H.S., GARCIA, L.C., LOYOLA, R., RODRIGUES, R.R., PILLAR, V.D. \& LEWINSOHN, T.M. 2016. A critical analysis of the Native Vegetation Protection Law of Brazil (2012): updates and ongoing initiatives. Nat. Conserv. 141-15.

BRASIL, M. do M.A. 2017. Estratégia e Plano de Ação Nacionais para a Biodiversidade [National Biodiversity Strategy and Action Plan]. Ministério do Meio Ambiente - MMA, Brasília, DF.

BRASIL, N.W.A. 2018. Brazilian Water Resources Report - 2017.

BRAY, M.V. du, STOTTS, R., BERESFORD, M., WUTICH, A. \& BREWIS, A. 2019. Does ecosystem services valuation reflect local cultural valuations? Comparative analysis of resident perspectives in four major urban river ecosystems. Econ. Anthropol. 6(1):21-33.

BRUM, Fernanda T., et al. 2019. "Forecasting conservation impact to pinpoint spatial priorities in the Brazilian Cerrado." Biological Conservation 240: 108283.

BUSTAMANTE, M.M.C. et al. 2019. Ecological restoration as a strategy for mitigating and adapting to climate change: lessons and challenges from Brazil. Mitig. Adapt. Strateg. Glob. Change.

CALMON, D.P. de G. 2017. The politics of contemporary agrarian frontiermaking: insights from Matopiba region, Brazil.

CARNEIRO, A., \& COSTA, K. 2016. The expansion of soybean production in the Cerrado: Paths to sustainable territorial occupation, land use and production.

CARPENTER, S.R., STANLEY, E.H. \& VANDER ZANDEN, M.J. 2011. State of the world's freshwater ecosystems: physical, chemical, and biological changes. Annu. Rev. Environ. Resour. 36(1):75-99.

CARRANZA, T., BALMFORD, A., KAPOS, V. \& MANICA, A. 2014. Protected area effectiveness in reducing conversion in a rapidly vanishing ecosystem: The Brazilian Cerrado. Conserv. Lett. 7(3):216-223.

CATTELAN, A.J. \& DALL'AGNOL, A., 2018. The rapid soybean growth in Brazil. Embrapa Soja-Artigo em periódico indexado (ALICE).

DE BARROS, P.H.B. \& STEGE, A.L., 2019. Deforestation and human development in the Brazilian agricultural frontier: an environmental Kuznets curve for MATOPIBA. Revista Brasileira de Estudos Regionais e Urbanos, 13(2), pp.161-182.

DE LUCENA, A.F.P., SZKLO, A.S., SCHAEFFER, R., DE SOUZA, R.R., BORBA, B.S.M.C., DA COSTA, I.V.L., JÚNIOR, A.O.P., DA CUNHA, S.H.F. 2009. The vulnerability of renewable energy to climate change in Brazil. Energ. Policy 37(3):879-889. https://doi.org/10.1016/j. enpol.2008.10.029

DÍAZ, S. et al. 2015. The IPBES Conceptual Framework - connecting nature and people. Curr. Opin. Environ. Sustain. 141-16.

DOUBEK, J.P., CAREY, C.C. \& CARDINALE, B.J. 2015. Anthropogenic land use is associated with $\mathrm{N}$-fixing cyanobacterial dominance in lakes across the continental United States. Aquat. Sci. 77(4):681-694.

EMBRAPA, E.B. de P.A. 2015. GeoWeb Matopiba. Matopiba.

FAO - FOOD AND AGRICULTURE ORGANIZATION OF THE UNITED NATIONS. 2015. Global forest resources assessment 2015.

FAO - FOOD AND AGRICULTURE ORGANIZATION OF THE UNITED NATIONS. 2016. The state of food and agriculture: climate change, agriculture and food security 2016.

FERRARINI, A.D.S.F., FILHO, J.B. de S.F., CUADRA, S.V. \& VICTORIA, D. de C. 2019. Water demand prospects for the irrigation in São Francisco River. Present. 22nd Annu. Conf. Glob. Econ. Anal. Wars. Pol. 
GARCIA, J.R. \& FILHO, J.E.R.V. 2018. O papel da dimensão ambiental na ocupação do MATOPIBA [The role of environmental dimension in the MATOPIBA occupation]. Confins (35):.

GIBBS, H.K., RAUSCH, L., MUNGER, J., SCHELLY, I., MORTON, D.C., NOOJIPADY, P., SOARES-FILHO, B., BARRETO, P., MICOL, L. \& WALKER, N.F. 2015. Brazil's Soy Moratorium. Science 347(6220):377-378.

GOLLNOW, F., HISSA, L. de B.V., RUFIN, P. \& LAKES, T. 2018. Propertylevel direct and indirect deforestation for soybean production in the Amazon region of Mato Grosso, Brazil. Land Use Policy 78377-385.

GOMES, L., SIMÕES, S., DALLA NORA, E., DE SOUSA-NETO, E., FORTI, M. \& OMETTO, J. 2019. Agricultural expansion in the Brazilian Cerrado: Increased soil and nutrient losses and decreased agricultural productivity. Land 8(1):12.

HUANG, Z., HAN, L., ZENG, L., XIAO, W. \& TIAN, Y. 2016. Effects of land use patterns on stream water quality: a case study of a small-scale watershed in the Three Gorges Reservoir Area, China. Environ. Sci. Pollut. Res. 23(4):3943-3955.

IPBES. 2016. The methodological assessment report on scenarios and models of biodiversity and ecosystem services. S. Ferrier, K. N. Ninan, P. Leadley, R. Alkemade, L. A. Acosta, H. R. Akçakaya, L. Brotons, W. W. L. Cheung, V. Christensen, K. A. Harhash, J. Kabubo-Mariara, C. Lundquist, M. Obersteiner, H. M. Pereira, G. Peterson, R. Pichs-Madruga, N. Ravindranath, C. Rondinini and B. A. Wintle (eds.). Secretariat of the Intergovernmental Science-Policy Platform on Biodiversity and Ecosystem Services, Bonn, Germany. 348 pages.

IPCC. 2014. Climate Change 2014: Synthesis Report. Contribution of Working Groups I, II and III to the Fifth Assessment Report of the Intergovernmental Panel on Climate Change. 151.

JANSE, J.H., KUIPER, J.J., WEIJTERS, M.J., WESTERBEEK, E.P., JEUKEN, M.H.J.L., BAKKENES, M.,ALKEMADE, R., MOOIJ, W.M. \& VERHOEVEN, J.T.A. 2015. GLOBIO-Aquatic, a global model of human impact on the biodiversity of inland aquatic ecosystems. Environ. Sci. Policy 4899-114.

JAX, K. 2019. Taking social responsibility in using ecosystem services concepts: Ethical issues of linking ecosystems and human well-being. In Atlas of Ecosystem Services (M. Schröter, A. Bonn, S. Klotz, R. Seppelt, \& C. Baessler, eds) Springer International Publishing, Cham, p.25-31.

KASTENS, J.H., BROWN, J.C., COUTINHO, A.C., BISHOP, C.R. \& ESQUERDO, J.C.D.M. 2017. Soy moratorium impacts on soybean and deforestation dynamics in Mato Grosso, Brazil K. P. Vadrevu, ed. PLOS ONE 12(4):e0176168.

LATAWIEC, A.E., STRASSBURG, B.B., BRANCALION, P.H.S., RODRIGUES, R.R. \& GARDNER, T. 2015. Creating space for large-scale restoration in tropical agricultural landscapes. Frontiers in Ecology and the Environment, 13, 211-218. 10.1890/140052.

LEVIS, C., FLORES, B.M., MAZZOCHINI, G.G., MANHÃES, A.P., CAMPOSSILVA, J.V., AMORIM, P.B., PERONI, N., HIROTA, M., CLEMENT, C.R. 2020. Help restore Brazil's governance of globally important ecosystem services. Nat. Ecol. Evol. 4: 172-173.

LOYOLA, R.D. 2014. Brazil cannot risk its environmental leadership. Divers Distrib. 20: 1365-1367. https://doi.org/10.1111/ddi.12252

LUNDQUIST, C.J. et al. 2017. Visions for nature and nature's contributions to people for the 21st century: report from an IPBES visioning workshop held on 4-8 September 2017 in Auckland, New Zealand.

MANSUR, A. 2017. Aárea de agricultura quase triplicou no Cerrado em 17 anos [In 17 years, Agriculture almost tripled in the Cerrado]. epoca.globo.com.

MARENGO, J.A. \& BERNASCONI, M. 2014. Regional differences in aridity/drought conditions over Northeast Brazil: present state and future projections. Climatic Change, 129(1-2), pp.103-115.

MARQUES, A., MARTINS, I.S., KASTNER, T., PLUTZAR, C., THEURL, M.C., EISENMENGER, N., HUIJBREGTS, M.A.J., WOOD, R., STADLER, K., BRUCKNER, M., CANELAS, J., HILBERS, J.P., TUKKER, A., ERB, K. \& PEREIRA, H.M. 2019. Increasing impacts of land use on biodiversity and carbon sequestration driven by population and economic growth. Nat. Ecol. Evol. 3(4):628-637.

MBONILE, M. J. 2005. Migration and intensification of water conflicts in the Pangani Basin, Tanzania. Habitat Int. 29(1):41-67.
MEA - MILLENNIUM ECOSYSTEM ASSESSMENT (PROGRAM), ed. 2005. Our human planet: summary for decision-makers. Island Press, Washington, [D.C.].

METZGER, J.P., BUSTAMANTE, M.M.C., FERREIRA, J., FERNANDES, G.W., LIBRÁN-EMBID, F., PILLAR, V.D., PRIST, P.R., RODRIGUES, R.R., VIEIRA, I.C.G. \& OVERBECK, G.E. 2019. Why Brazil needs its Legal Reserves. Perspect. Ecol. Conserv. 17(3):91-103.

MIRANDA, E.E. de, MAGALHÃES, L.A. \& CARVALHO, C.A. de. 2014 Proposta de Delimitação Territorial do MATOPIBA [Proposed Territorial Delimitation of MATOPIBA]. Nota Técnica. Embrapa. Nota Técnica GITE, 1. Campinas: Embrapa, May 2014. 18. https://ainfo.cnptia.embrapa.br/ digital/bitstream/item/139202/1/NT1-DelimitacaoMatopiba.pdf.

NEPSTAD, D., MCGRATH, D., STICKLER, C., ALENCAR, A., AZEVEDO, A., SWETTE, B., BEZERRA, T., DIGIANO, M., SHIMADA, J., SEROA DA MOTTA, R., ARMIJO, E., CASTELLO, L., BRANDO, P., HANSEN, M.C., MCGRATH-HORN, M., CARVALHO, O. \& HESS, L. 2014. Slowing Amazon deforestation through public policy and interventions in beef and soy supply chains. Science 344(6188):1118-1123.

NEUPANE, R. P., WHITE, J. D., ALEXANDER, S. E. 2015. Projected hydrologic changes in monsoon-dominated Himalaya Mountain basins with changing climate and deforestation. J. Hydrol. 525:216-230.

NICHOLSON, E., FULTON, E., BROOKS, T., BLANCHARD, R., LEADLYE, P., METZGER, J., MOKANY, K., STEVENSON, S., WINTLE, B., WOOLLEY, S., BARNES, M., WATSON, J., FERRIER, S. 2019. Scenarios and Models to Support Global Conservation Targets. Trends in Ecology \& Evolution. 34(1): 57-68. https://doi.org/10.1016/j.tree.2018.10.006

NOBRE, R.L.G., CALIMAN, A, RODRIGUES C, de CARVALHO, F., GUÉRIN, J., da COSTA, F., BARBOSA, L., MARTINS, E., DETTOGNI, R., MEGALI, A., KELLY, P., VANNI, M., SILVA, L. 2020. Precipitation, landscape properties and land use interactively affect water quality of tropical freshwaters. Sci. Total Environ. 716:137044.

NUNES, J.P., JACINTO, R., KEIZER, J.J. 2017. Combined impacts of climate and socio-economic scenarios on irrigation water availability for a dry Mediterranean reservoir. Sci. Total Environ. 584-585:219-233. https://doi. org/10.1016/j.scitotenv.2017.01.131

OECD/FOOD AND AGRICULTURE ORGANIZATION OF THE UNITED NATIONS. 2015. OECD-FAO Agricultural Outlook 2015,OECD Publishing, Paris. http://dx.doi.org/10.1787/agr_outlook-2015-en.

PAERL, H.W. \& OTTEN, T.G. 2013. Harmful cyanobacterial blooms: Causes, consequences, and controls. Microb. Ecol. 65(4):995-1010.

PAERL, H.W. \& PAUL, V.J. 2012. Climate change: Links to global expansion of harmful cyanobacteria. Water Res. 46(5):1349-1363.

PAIVA, R.J.O., BRITES, R.S. \& MACHADO, R.B. 2015. The role of protected areas in the avoidance of anthropogenic conversion in a high pressure region: a matching method analysis in the core region of the Brazilian Cerrado. PLOS ONE 10(7):e0132582.

PIRES, A.P.F., AMARAL, A.G., PADGURSCHI, M.C.G., JOLY, C.A. \& SCARANO, F.R. 2018. Biodiversity research still falls short of creating links with ecosystem services and human well-being in a global hotspot. Ecosyst. Serv. 3468-73.

PITTA, F.T. \& VEGA, G.C. 2017. Impacts of agribusiness expansion in the Matopiba region: Communities and the environment. ActionAid.

POUSA, R., COSTA, M.H., PIMENTA, F.M., FONTES, V.C., BRITO, V.F.A.D. AND CASTRO, M. 2019. Climate Change and Intense Irrigation Growth in Western Bahia, Brazil: The Urgent Need for Hydroclimatic Monitoring. Water, 11(5), p.933.

QIU, J. \& TURNER, M.G. 2015. Importance of landscape heterogeneity in sustaining hydrologic ecosystem services in an agricultural watershed. Ecosphere 6(11):art229.

RESENDE, F.M., CIMON-MORIN, J., POULIN, M., MEYER, L. \& LOYOLA, R. 2019. Consequences of delaying actions for safeguarding ecosystem services in the Brazilian Cerrado. Biol. Conserv. 23490-99.

REUVENY, R. 2007. Climate change-induced migration and violent conflict. Polit. Geogr. 26(6):656-673 
RORIZ, P.A.C., YANAI, A.M. \& FEARNSIDE, P.M. 2017. Deforestation and carbon loss in southwest Amazonia: Impact of Brazil's revised Forest Code. Environ. Manage. 60(3):367-382.

ROSA, I.M.D. et al. 2017. Multiscale scenarios for nature futures. Nat. Ecol. Evol. 1(10):1416-1419.

SANO, E.E. et al. 2019. Land use dynamics in the Brazilian Cerrado in the period from 2002 to 2013. Pesqui. Agropecuária Bras. 54.

SANO, E.E., ROSA, R., BRITO, J.L.S. \& FERREIRA, L.G. 2010. Land cover mapping of the tropical savanna region in Brazil. Environ. Monit. Assess. 166(1):113-124.

SAUER, S. 2018. Soy expansion into the agricultural frontiers of the Brazilian Amazon: The agribusiness economy and its social and environmental conflicts. Land Use Policy 79:326-338.

SCARANO, F.R. 2019. The Emergence of Sustainability. In Emergence and Modularity in Life Sciences ( L.H. Wegner \& U. Lüttge, eds.). Springer, Cham, p.51-71.

SCHEFFRAN, J. \& BATTAGLINI, A. 2011. Climate and conflicts: the security risks of global warming. Reg. Environ. Change 11(1):27-39. https://doi. org/10.1007/s10113-010-0175-8

SCHILLING, K. E., JHA, M. K., ZHANG, Y-K., GASSMAN, P. W. \& WOLTER, C. F. 2008. Impact of land use and land cover change on the water balance of a large agricultural watershed: Historical effects and future directions. Water Resour. Res. 44:W00A09.

SCHNEIDER, F., KALLIS, G. \& MARTINEZ-ALIER, J. 2010. Crisis or opportunity? Economic degrowth for social equity and ecological sustainability. Introduction to this special issue. J. Clean. Prod. 18(6):511-518.

SCHOLES, R.J. et al. 2018. IPBES (2018): Summary for policymakers of the assessment report on land degradation and restoration of the Intergovernmental Science- Policy Platform on Biodiversity and Ecosystem Services. Intergovernmental Science-Policy Platform on Biodiversity and Ecosystem Services.

SCHOOLENBERG, M. et al. 2018. Report on the workshop "Next Steps in Developing Nature Futures.” PBL Neth. Environ. Assess. Agency.

SOARES-FILHO, B., RAJAO, R., MACEDO, M., CARNEIRO, A., COSTA, W., COE, M., RODRIGUES, H. \& ALENCAR, A. 2014. Cracking Brazil's Forest Code. Science 344(6182):363-364.

SOTERRONI, A.C., MOSNIER, A., CARVALHO, A.X.Y., CÂMARA, G., OBERSTEINER, M., ANDRADE, P.R., SOUZA, R.C., BROCK, R., PIRKER, J., KRAXNER, F., HAVLÍK, P., KAPOS, V., ZU ERMGASSEN, E.K.H.J., VALIN, H. \& RAMOS, F.M. 2018. Future environmental and agricultural impacts of Brazil's Forest Code. Environ. Res. Lett. 13(7):074021.

SOTERRONI, A.C., RAMOS, F.M., MOSNIER, A., FARGIONE, J., ANDRADE, P.R., BAUMGARTEN, L., PIRKER, J., OBERSTEINER, M., KRAXNER, F., CÂMARA, G., CARVALHO, A.X.Y. \& POLASKY, S. 2019. Expanding the Soy Moratorium to Brazil's Cerrado. Sci. Adv. 5(7):eaav7336.
SPERA, S.A., GALFORD, G.L., COE, M.T., MACEDO, M.N. \& MUSTARD, J.F. 2016. Land-use change affects water recycling in Brazil's last agricultural frontier. Glob. Change Biol. 22(10):3405-3413.

STRASSBURG, B.B.N., BROOKS, T., FELTRAN-BARBIERI, R., IRIBARREM, A., CROUZEILLES, R., LOYOLA, R., LATAWIEC, A.E., OLIVEIRA FILHO, F.J.B., SCARAMUZZA, C.A. de M., SCARANO, F.R., SOARES-FILHO, B. \& BALMFORD, A. 2017. Moment of truth for the Cerrado hotspot. Nat. Ecol. Evol. 1(4):0099.

SUN, G., MCNULTY, S. G., MYERS, J. A. M. \& COHEN, E. C. 2008. Impacts of multiple stresses on water demand and supply across the southeastern United States. J. Am. Water Resour. As. 44(6):1441-1457.

UNDP. 2018. Human Development Indices and Indicators. 2018 Statistical Update. United Nations Development Programme. 123.

U. N. GENERALASSEMBLY. 2015. Transforming our World: The 2030 Agenda for Sustainable Development. United Nations. p. 1 - 35.

VALERA, C., PISSARRA, T., FILHO, M., VALLE JÚNIOR, R., OLIVEIRA, C., MOURA, J., SANCHES FERNANDES, L. \& PACHECO, F. 2019. The buffer capacity of riparian vegetation to control water quality in anthropogenic catchments from a legally protected area: A critical view over the Brazilian New Forest Code. Water 11(3):549.

VAN VLIET, M.T.H., WIBERG, D., LEDUC, S. \& RIAHI, K. 2016. Powergeneration system vulnerability and adaptation to changes in climate and water resources. Nat. Clim. Change 6(4):375-380. https://doi.org/10.1038/ nclimate2903

VELDKAMP, T.I.E., WADA, Y., AERTS, J.C.J.H., DÖLL, P., GOSLING, S.N., LIU, J., MASAKI, Y., OKI, T., OSTBERG, S., POKHREL, Y., SATOH, Y., KIM, H. \& WARD, P.J. 2017. Water scarcity hotspots travel downstream due to human interventions in the 20th and 21 st century. Nat. Commun. $8(1): 15697$

VIEIRA, R.R.S., RIBEIRO, B.R., RESENDE, F.M., BRUM, F.T., MACHADO, N., SALES, L.P., MACEDO, L., SOARES-FILHO, B. \& LOYOLA, R. 2018. Compliance to Brazil's Forest Code will not protect biodiversity and ecosystem services B. Larson, ed. Divers. Distrib. 24(4):434-438.

VITOUSEK, P.M., MOONEY, H.A., LUBCHENCO, J. \& MELILLO, J.M. 1997. Human domination of Earth's ecosystems. Science 277(5325):494-499.

WILSON, E.O. 2016. Half-earth: our planet's fight for life. Liveright Publishing Corporation, New York.

ZAKIA, M.J. \& PINTO, L.F.G. 2013. Guia para aplicação da nova lei florestal em propriedades rurais [Guide to applying the new Forest law on rural properties]. Imaflora, Piracicaba.

ZALleS, V., HANSEN, M.C., POTAPOV, P.V., STEHMAN, S.V., TYUKAVINA, A., PICKENS, A., SONG, X.-P., ADUSEI, B., OKPA, C., AGUILAR, R., JOHN, N. \& CHAVEZ, S. 2019. Near doubling of Brazil's intensive row crop area since 2000. Proc. Natl. Acad. Sci. 116(2):428-435.

Received: $18 / 10 / 2019$

Revised: 13/03/2020

Accepted: 08/04/2020

Published online: 01/06/2020 